\author{
РЕЦЕНЗИЯ НА КНИГУ \\ История Испании. \\ Том 2. От войны за испанское наследство до начала XXI века I \\ Институт всеобщей истории РАН. М.: «Индрик», 2014. 872 с., ил. \\ Ответственные редакторы тома: \\ О.В. Волосюк, М.А. Липкин, Е.Э. Юрчик
}

\author{
А.Ю. Борзова \\ Российский университет дружбы народов \\ ул. Миклухо-Маклая, 6, Москва, Россия, 117198
}

Ключевые слова: Испания, история, исследование, дипломатические отношения, Россия

В феврале 2017 г. исполнилось 40 лет с момента восстановления дипломатических отношений между Испанией и Россией. Отношения между двумя странами имеют давние и прочные традиции, несмотря на сложности и противоречия. Восстановление дипломатических отношений в 1977 г. привело в нашей стране к росту интереса к истории Испании, ее культуре, традициям, росту контактов с научными организациями и ведущими университетами двух стран, работе в архивах двух стран. Внимание российских испанистов привлекает и внешняя политика Испании [2], и деятельность российских дипломатов в этой стране [3], отдельные аспекты исследований испанских авторов [4]. Встречи историков России и Испании, реализация совместных проектов в гуманитарной сфере оказали положительное влияние на развитие российской исторической испанистики.

Важным шагом в развитии российской испанистики стало создание фундаментальной «Истории Испании», над которой работала группа ведущих испанистов из ИВИ РАН, МГУ имени М.В. Ломоносова, РГГУ, НИУ ВШЭ, МГЛУ, ИЛА РАН.

В 2012 г. вышел первый том «Истории Испании» (отв. ред. В.А. Ведюшкин, Г.А. Попова), который включил в себя эпохи древности, Средних веков и раннего Нового времени. 
В 2014 г. увидел свет второй том Истории Испании. От войны за испанское наследство до начала XXI века / Институт всеобщей истории РАН. М., «Индрик», 2014. - 872 с. ил. Ответственные редакторы тома: О.В. Волосюк, М.А. Липкин, Е.Э. Юрчик.

В первой главе этого издания представлено первое в России последовательное изложение истории Испании XVIII в., начало которого в Испании было связано со сменой династии Габсбургов на Бурбонов, когда на престоле оказался молодой Филипп V, внук короля Франции Людовика XIV [1. C. 23-42]. Сложные перипетии с престолонаследием привели к войне за испанское наследство, глобальному конфликту, охватившему всю Европу в 1701-1714 гг. В результате этого потрясения владения испанской монархии сократились, международный престиж был утрачен, имперское величие ушло в прошлое [1. С. 42-47]. И новая династия вступает на путь реформ, которые и составили сущность государственно-политической истории Испании XVIII в. Административные реформы в стране содействовали изменению системы государственного управления. Военная реформа, финансовые и налоговые преобразования содействовали хозяйственному подъему страны. В работе хорошо и полно показана противоречивость этого периода испанской истории, представлена «Просвещенная монархия» Карла III, экономические реформы и финансовые нововведения, стремление к интеллектуальному обновлению, отразившееся в работах испанских мыслителей этого периода [1. С. 57-77].

Авторы отмечают, что своеобразие и архаичность общественных и политических отношений, так называемый «старый порядок», оказался устойчивым и к военному кризису, и к либеральным реформам, и именно поэтому XIX в. становится временем новых испытаний для Испании. Череда политических переворотов, непоследовательные конституционные и общественно-экономические преобразования классифицировались современниками как «революция», поскольку подразумевали прежде всего государственный переворот. Авторы исследования обоснованно указывают, что «революционную репутацию» в классическом понимании можно сохранить только за тремя событиями этого века - войной за независимость 1808-1814 гг, когда страна была занята войсками Наполеона, периодом первой карлистской войны 1833-1840 гг. и «демократическим шестилетием» 1868-1874 гг., когда в Испании можно говорить о «выборной монархии» и федеративной республике [1. С. 201-230, 327-346].

Период Реставрации монархии, политические преобразования и экономическая ситуация в стране, особенности испанской промышленной революции, социальные проблемы нейтрализовали, но не устранили традиционные конфликты и не смогли предотвратить появления новых проблем.

Как отмечено авторами, стабилизация оказалась временным затишьем перед «катастрофой 1898 г.», когда в результате поражения в войне с США из- 
за Кубы Испания лишилась последних заокеанских владений и превратилась во второразрядное европейское государство [1. С. 437-442].

В исследовании показано, как на протяжении всего XIX в. ослабевали позиции Испании в мировой политике, а сложная внутренняя ситуация, связанная с гражданским противостоянием, привела к тому, что европейские державы, прежде всего Франция и Великобритания, вмешивались в испанские дела.

Потеря почти всех заокеанских владений, революции и частая смена правительств, социально-экономические трудности привели к тому, что Испания оказывается на периферии мировой политики, а многочисленные внешнеполитические авантюры, связанные со стремлением Испании вернуть себе утраченные позиции, не принесли выгод для страны.

Испания в XX в., как показано в работе, устраняется от участия в первой и второй мировой войнах, но при этом страна испытала трагедию гражданского противостояния, глобального по своему влиянию на исторический процесс. Гражданская война 1936-1939 гг. оказывается одним из ключевых событий мировой истории XX в. благодаря двум обстоятельствам: интернационализации конфликта и глубине социальных преобразований этого периода [1. С. 487-517].

Авторы дают хронологию трагических событий гражданской войны, выявляют политические противоречия в рядах республиканцев, выявляют причины их поражения, рассматривают деятельность Коминтерна (Глава 3). В итоге прямое столкновение двух испанских режимов завершилось победой связанного с фашистскими державами франкизма. Подавление революционного импульса в Республике ослабило принципиальную альтернативность «двух Испаний» и поставило республиканцев в полную зависимость от внешнеполитических факторов [1. С. 563-572]. Блокада со стороны западноевропейских стран и вынужденное ослабление вмешательства СССР в конфликт, как справедливо отмечено в работе, обрекли испанцев на поражение.

Наряду с освещением процесса формирования франкистского государства в работе дан анализ идеологии франкизма, где наиболее важными течениями были католицизм и фашизм, а главным проводником была фаланга. Именно фаланга привнесла в идеологию франкизма идею, превратившую военное восстание в «национальную революцию» [1. С. 575-587].

Режим Ф. Франко, установленный в Испании в 1939 г., за почти сорок лет своего существования прошел долгий и сложный путь эволюции, с постепенным отходом от тоталитаризма и появлением идей «развития», экономической модернизации, поддержки среднего класса. Постепенное возрождение гражданского общества в стране создает условия для мирного перехода от франкизма к демократии, что нашло отражение в этом исследовании, где представлен анализ этого переходного периода, изучена политика правительства социалистов и деятельности Народной партии. Именно институт монархии 
в лице Хуана Карлоса I содействовал процессу обновления страны, расширению ее присутствия на мировой арене. Испания быстро достигает значительного уровня развития демократических институтов, укрепляет новую коллективную идентичность в «государстве автономий», становится важным актором в международных отношениях, преодолевает сложную кризисную ситуацию [1. С. 622-635].

Несомненным достоинством этого тома является широкое освещение российско-испанских отношений во второй половине XIX в., и в сложный период гражданской войны, и после восстановления дипломатических отношений между двумя странами. Кроме того, в работе представлена культура Испании XIX в., культурная жизнь в условиях франкизма, серебряный век испанской культуры, а также культура современной Испании.

Это фундаментальное исследование внесло значительный вклад в развитие российской испанистики. Оно не только впервые представило полноценную картину испанской истории XVIII в., но и предложило новую периодизацию истории Испании XIX в., продемонстрировало новые подходы к осмыслению и пониманию сложных этапов развития Испании в XX-XXI вв.

Представленный второй том Истории Испании. От войны за испанское наследство до начала XXI века сопровождается хронологическим указателем, списком карт и именным указателем, что облегчает работу исследователя. Обширная библиография (1. С. 767-817), включающая работы ведущих российских и испанских историков, политологов, философов, деятелей искусства и культуры, открывает возможности для дальнейшего изучения различных аспектов истории Испании, ее внутренней и внешней политики.

(C) Борзова А.Ю., 2017

\section{ЛИТЕРАТУРА}

[1] История Испании. Том 2. От войны за испанское наследство до начала XXI века / Институт всеобщей истории РАН. М., «Индрик», 2014. 872 с., ил.

[2] Аникеева Н.Е., Ведюшкин В.А., Волосюк О.В., Медников И.Ю., Пожарская С.П. История внешней политики Испании. М.: Международные отношения, 2014. 504 с.

[3] Российские дипломаты в Испании Diplomaticos rusos en Espana. 1667-2017 / Отв. ред. О.В. Волосюк. М.: Международные отношения, 2016. 672 с., ил.

[4] Борзова А.Ю. Изучение проблем европейской безопасности в работах испанских внешнеполитических центров // Вестник РУДН: Серия Международные отношения. М.: РУДН, 2011. № 4. С. 5-15. 


\title{
REVIEW: \\ History of Spain. \\ Volume 2. From the war for the Spanish inheritance \\ to the beginning of the XXI century / Institute of World History of the Russian Academy of Sciences. M.: "Indrik", 2014. 872 p., ill.
}

\author{
A.U. Borzova \\ Peoples' Friendship University of Russia \\ 10a Miklukho-Maklaya St., Moscow, Russia, 117198
}

Key words: Spain, history, research, diplomatic relations, Russia

\section{REFERENCES}

[1] History of Spain. Volume 2. From the war for the Spanish inheritance to the beginning of the XXI century / Insttute of World History of the Russian Academy of Sciences. M., «Indrik», 2014. $872 \mathrm{p}$.

[2] Anikeeva N.E, Vedushkin V.A, Volyusuk O.V, Mednikov I.Yu., Pozharskaya S.P. The History of Foreign Policy of Spain. M.: International Relations. $504 \mathrm{~s}$.

[3] Russian diplomats in Spain. Diplomaticos rusos en Espana. 1667-2017 / Red. O.V. Volosyuk. M.: International Relations. 2016. 672 p.

[4] Borzova A.Yu. The study of the problems of European security in the work of Spanish foreign policy centers // Bulletin of the Peoples' Friendship University of Russia, series International Relations. M.: RUDN, 2011. No. 4. P. 5-15.

\section{Сведения об авторе:}

Борзова Алла Юрьевна - доктор исторических наук, доцент кафедры теории и истории международных отношений Российского университета дружбы народов.

E-mail:bau845@mail.ru 